\title{
DIGITAL RIGHTS MANAGEMENT SEBAGAI SOLUSI KEAMANAN DOKUMEN ELEKTRONIK
}

\author{
Agus Kurniawan \\ Fakultas Ilmu Komputer, Universitas Indonesia, Depok, Indonesia \\ agusk@cs.ui.ac.id
}

\begin{abstract}
Abstrak
Perkembangan dokumen elektronik yang pesat dan mudah diakses berdampak semakin sulitnya dalam membatasi informasi ketika ingin membatasi akses terhadap informasi pada dokumen elektronik. Oleh karena itu, diperlukan mekanisme untuk menjaga informasi pada dokumen elektronik hanya dapat diakses oleh yang berhak dan tersimpan dengan aman. Pendekatan solusi dapat menerapkan Digital Rights Management pada dokumen elektronik sehingga pemilik dokumen elektronik aka lebih aman menyimpannya ataupun melakukan sharing ke partnernya.
\end{abstract}

Kata kunci : Digital Rights Managements, Security System

\section{Pendahuluan}

Perkembangan komputer yang makin pesat mempengaruhi kebiasaan seseorang terutama pada kebutuhan dokumen. Dokumen konvensional yang ditulis diatas kertas lambat laun bergeser dengan dokumen elektronik [1,2]. Bahkan dokumen elektronik sekarang sudah mempunyai kekuatan hukum. Hal ini membuat naiknya pemakaian dokumen elektronik.

Sifat dokumen elektronik yang fleksibel untuk diedit, digandakan ataupun didistribusikan membuat semakin banyak orang cenderung bekerja pada dokumen berbasis elektronik dibandingkan dengan bekerja dengan dokumen konvensional.

Pada saat ini, begitu banyak dokumen elektronik yang dibuat dengan mudah melalui komputer seiring berkembangnya aplikasi pengolah data dokumen. Pada kasus tertentu, beberapa dokumen tersebut mungkin ada dokumen yang dapat dikategorikan sebagai dokumen rahasia. Dokumen ini hanya dapat dibaca atau diberikan pada orang-orang tertentu. Oleh karena itu diperlukan mekanisme atau metode bagaimana mengamankan dokumen elektronik.

\subsection{Tujuan}

Tujuan utama yang hendak dicapai adalah mendesain suatu model sistem untuk mengamankan dokumen eletronik dari orang yang tidak mempunyai hak mengakses.

\section{Landasan Teori}

\subsection{Digital Rights Management}

Digital Right Management (DRM) system adalah istilah yang digunakan untuk mengatur data digital dan memproteksinya dari user yang tidak mempunyai hak akses [3]. DRM dapat berasal dari banyak bentuk antara lain:

- Dokumen

- Gambar

- Musik

- Video

- dan sebagainya

Data digital ini selanjutnya oleh pemiliknya diamankan agar hanya orang-orang tertentu saja yang dapat mengaksesnya.

Penerapan DRM dapat melibatkan banyak metode bahkan setiap vendor besar seperti Sony, Microsoft, Apple, dan Adobe mempunyai mekanisme sendiri. Sebagai contoh, Microsoft menerapkan DRM pada produk Windows Media, Operating System Windows dan Microsoft Office [4].

\subsection{Metadata}

Beberapa metode untuk menerapkan DRM pada data digital dengan memasukkan informasi tertentu pada bentuk metadata kedalam data tersebut. Informasi metadata biasanya meliputi nama, informasi account atau e-mail.

Metadata juga diterapkan pada data komersial contohnya Apple's iTunes yang meletakan data DRM yang dimasukkan kedalam MPEG standard metadata [5]. 


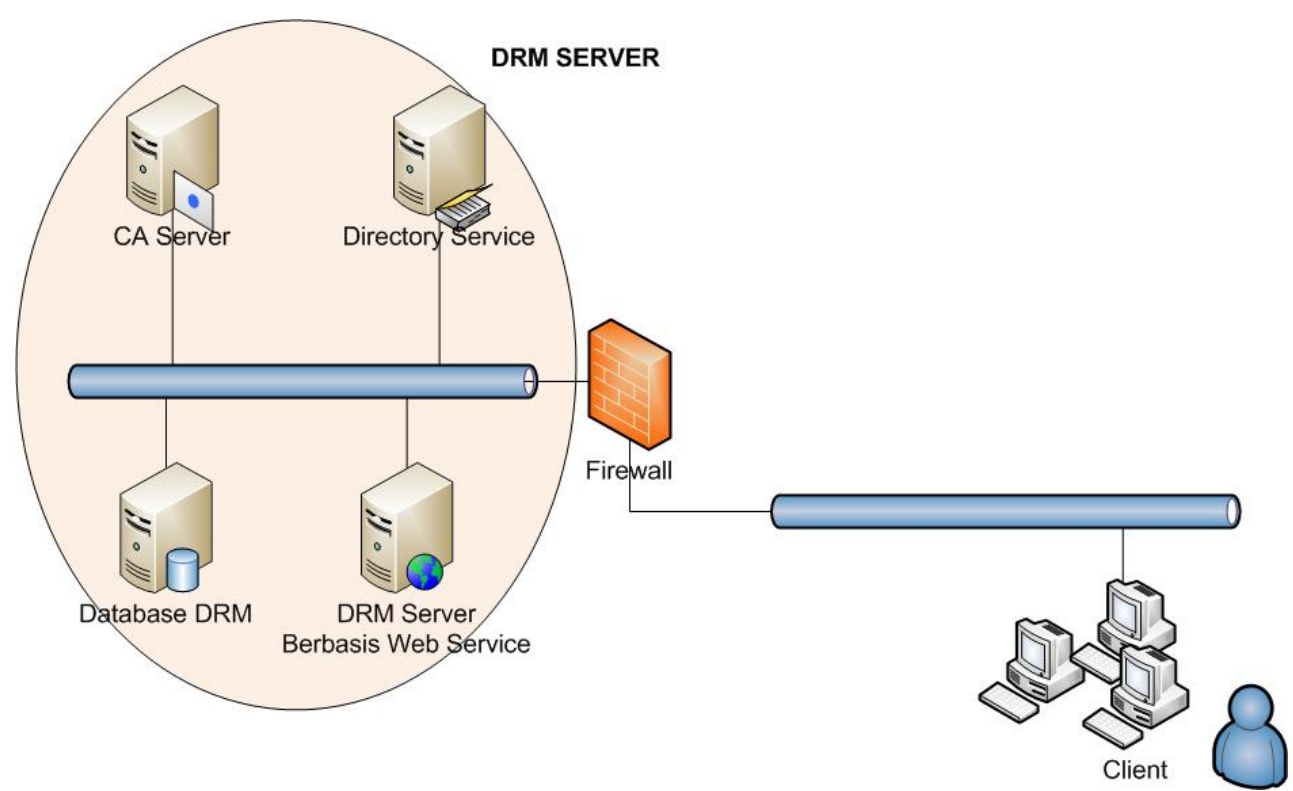

Gambar 1. Design logical pada sistem DRM

\section{Analisa}

\subsection{Design Umum}

Setiap dokumen elektronik yang telah dibuat dan ingin memproteksi informasi didalamnya maka dokumen elektronik tersebut dapat dilakukan proses DRM. Proses ini melibatkan enkripsi berbasis Cryptography yang mempunyai public key dan private key. Sistem yang menghasilkan public dan private key dapat berperan sebagai license server.

Secara umum, implementasi aplikasi yang menerapkan DRM dapat menggunakan pendekatan arsitektur client-server seperti terlihat pada Gambar 1. Server disini menyediakan servis untuk melayani:

- Menghasilkan public dan private key setiap dokumen elektronik yang akan diterapkan DRM

- Menghasilkan license yang berisi informasi hak apa saja dapat ditujukan pada dokumen tersebut

- Menyimpan semua data DRM setiap dokumen. Dalam hal ini dilakukan pada bagian database server

Semua komponen yang terlibat dimasukkan ke dalam domain direktori yang sama sehingga sistem authentikasi dan authorisasi dapat dikontrol secara terpusat.

\subsection{DRM Server}

DRM Server merupakan bagian terpenting untuk melakukan proses DRM pada suatu dokumen elektronik. Komponen ini bertanggung jawab mengatur dokumen elektronik yang akan diamankan termasuk manajemen cryptography key. Komponen DRM Server meliputi;
- DRM Server berbasis Web Service

- DRM Database Server

- Directory Service

- CA Server

Masing-masing item akan dijelaskan pada subjudul selanjutnya.

\subsubsection{DRM Server Berbasis Web Service}

DRM Server berbasis Web Service berfungsi sebagia web interface antara server dan client. Penerapan model Web Service diharapkan sistem dapat berfungsi SOA (Service-Oriented Architecture). Client yang ingin berkomunikasi dengan DRM Server cukup menerapkan standard SOA yang telah didefinisikan.

Desain untuk DRM Server berbasis web service dapat dilihat pada Gambar 2. Aplikasi DRM server berjalan diatas suatu web server. Realisasi DRM server memerlukan komponen antara lain

- Application Server

Aplikasi ini sebagai container untuk aplikasi web server contohnya dalam hal ini adalah ASP.NET, PHP dan JSP

\section{- DRM}

Aplikasi modul yang menyediakan hal-hal yang berhubungan dengan DRM

- Web Service / SOA

Modul atau library yang menyediakan kontruksi dan dekontriksi skema SOA. Modul ini juga bertindak sebagai interface antara aplikasi server DRM dan client yang mengkonsumsi DRM. 


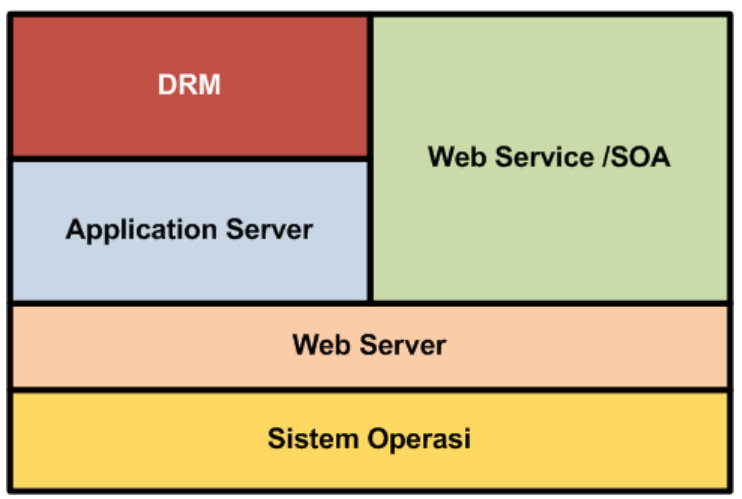

Gambar 2. Design DRM server berbasis web service

Apabila user yang menggunakan aplikasi ini sangat banyak atau intensitas pembuatan dokumen yang diamankan cukup banyak maka DRM server pada web server dapat dipertimbangan untuk diterapkan clustering. Cara umum yang dapat digunakan adalah Network Load Balancing (NLB). Metode ini sangat cocok untuk web server. Implementasi dapat dilihat pada Gambar 3.

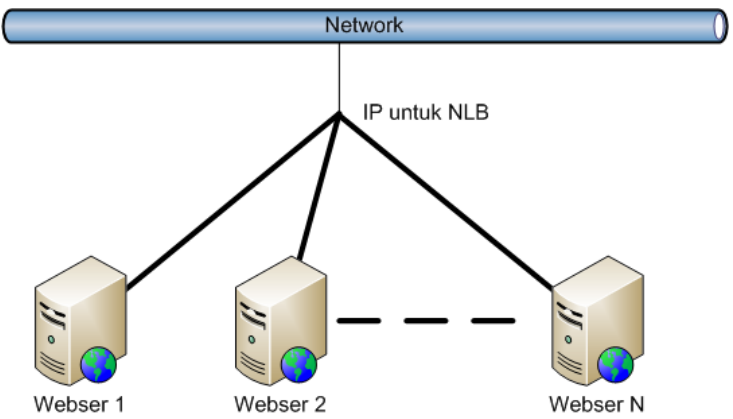

Gambar 3. DRM Web server untuk NLB

Implementasi NLB pada web server memerlukan satu IP virtual yang mana semua yang ingin mengakses web server harus melalui IP virtual ini.

\subsubsection{DRM Database Server}

DRM Database Server berfungsi sebagai penyimpan semua key yang dihasilkan oleh DRM. Selain itu dokumen original yang sudah terenkripsi dapat disimpan pada database ini.

Hal yang perlu diperhatikan dalam memilih database yaitu performance dan kapasitanya. Ini dikarenakan semua key dan dokumen tersimpan ke dalam database ini. Beberapa pilihan database yang dapat digunakan yaitu SQL Server, Oracle, dan MySQL.

Apabila availability merupakan hal penting dan utama maka database yang digunakan harus didesain sebagai database cluster atau failover. Dengan pendekatan ini, jika ada mesin database yang mati maka mesin database lainnya tetap dapat melayani.

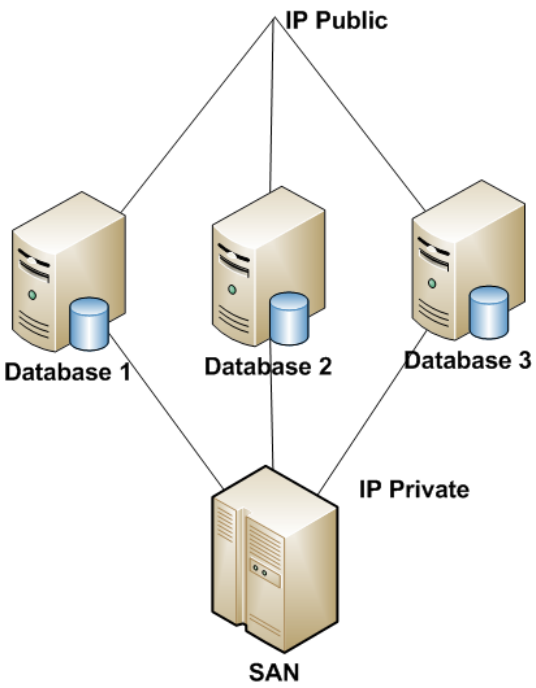

Gambar 4. Penerapan database sebagai failover cluster

Realisasi database cluster dapat dilihat pada Gambar 4. Setiap mesin minimal mempunyai 2 Network Interface Controller (NIC) dimana satu NIC akan dikonfigurasi sebagai IP public atau cluster dan satu NIC untuk IP private yang berguna untuk mengakses external storage (misalkan SAN).

Melalui IP public ini digunakan sebagai IP yang dikenali oleh client atau server yang ingin mengakses database tersebut. Mesin database mana yang aktif akan ditangani oleh database cluster itu sendiri.

\subsubsection{Directory Service}

Directory Service berfungsi sebagai identitas dari entitas yang terlibat pada transaksi yang terjadi. Setiap client yang mengakses ke DRM Server sebelumnya akan dilakukan pengecekan apakah client tersebut memang member yang mempunyai hak untuk mengakses DRM Server atau tidak.

Directory service dapat dikatakan seperti database karena ini dapat menyimpanan informasi profil user seperti nama, alamat, email dan sebagainya. Selain berisi profil user, Directory service dapat digunakan untuk security directory dimana kita dapat mendefinisikan hak akses setiap user atau group.

Implementasi Directory service biasanya mengikuti standar yang ada yaitu LDAP/X.500. Beberapa perusahan besar juga mengimplementasi Directory service berbasis LDAP/X.500 seperti Microsoft, Novell, IBM, SUN, APACHE, RED HAT. Contoh implementasi Directory service pada Microsoft adalah Active Directory (AD). Ini dapat ditemukan pada sistem operasi Windows Server 2000, 2003, dan 2008. Sebagai contoh AD Windows 
Server 2008 seperti pada Gambar 5.

Penggunaan Directory service untuk DRM berguna sebagai identity management artinya setiap kejadian pada DRM harus dikenali oleh Directory service. Oleh karena itu, setiap user akan mempunyai identitas yang tersimpan di dalam Directory service.

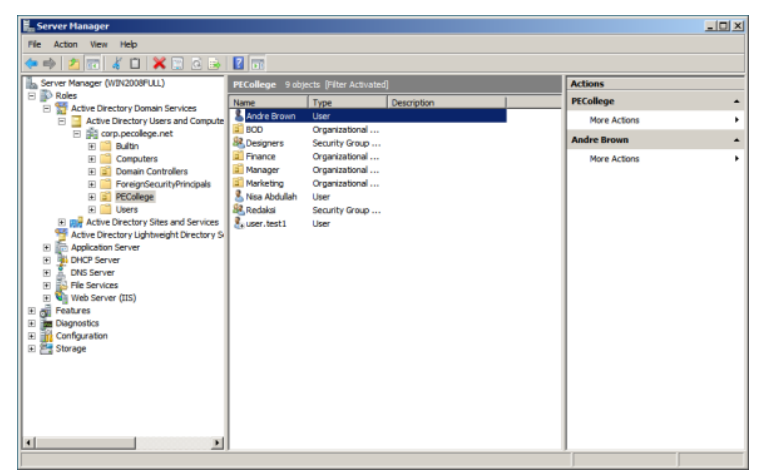

Gambar 5. Implementasi Directory service pada Windows Server 2008

\subsubsection{Certificate Authority}

CA (Certificate Authority) Server berfungsi certificate approval yang memberikan otoritas bahwa certificate yang digunakan untuk DRM pada dokumen itu valid atau tidak.

Disarankan CA yang digunakan untuk DRM dikeluarkan oleh suatu lembaga yang dapat dipercaya contohnya Verisign. CA akan diinstall pada DRM server terutama yang melakukan publikasi certificate ke client.

CA yang sudah diperoleh dari lembaga yang dipercaya dapat langsung di-install pada web server dimana DRM server terinstall contohnya seperti Gambar 6.

\subsection{DRM Client}

Pada dasarnya semua aplikasi dokumen yang ada pada komputer client dapat memanfaatkan fasilitas DRM dengan catatan aplikasi tersebut mengetahui proses DRM tersebut.

Apabila aplikasi tersebut tidak mengenal sistem DRM ini maka ketika aplikasi membuka dokumen tersebut maka akan terjadi kesalahan pembacaan karena isi dokumen tersebut sudah terenkripsi. Sedangkan aplikasi yang mengenal atau aware terhadap DRM maka aplikasi ini dapat berkomunikasi dengan DRM Server mulai dari mendapatkan Certificate, Cryptography Key dan proses enkripsi dan dekripsi.

Aplikasi client yang ada dapat juga diintegrasikan dengan DRM dengan pendekatan Add-on artinya menambah modul baru pada aplikasi tersebut.

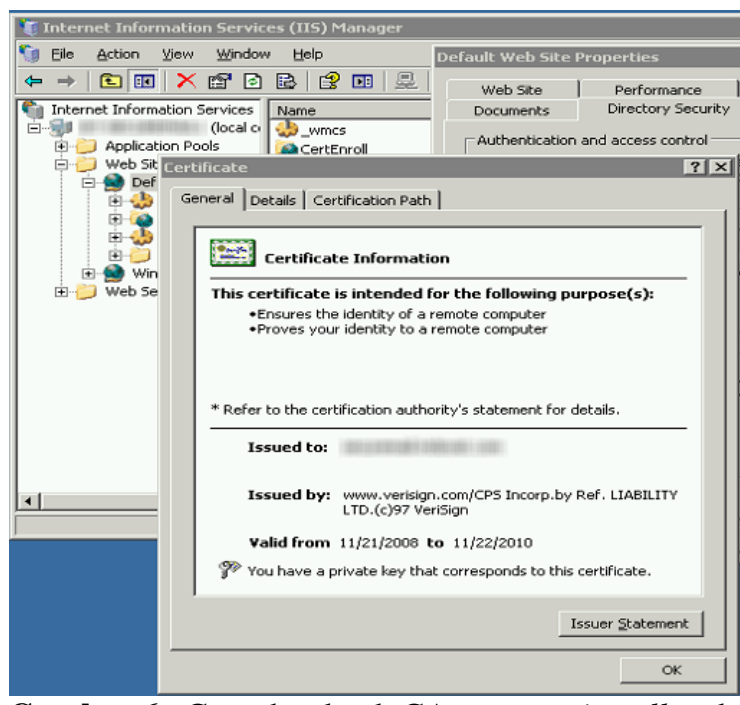

Gambar 6. Contoh sebuah CA yang ter-install pada web server

Beberapa aplikasi komersial contohnya Micrsooft Office 2007 sudah support untuk DRM melalui Microsoft Right Management Services seperti yang terlihat pada Gambar 7.

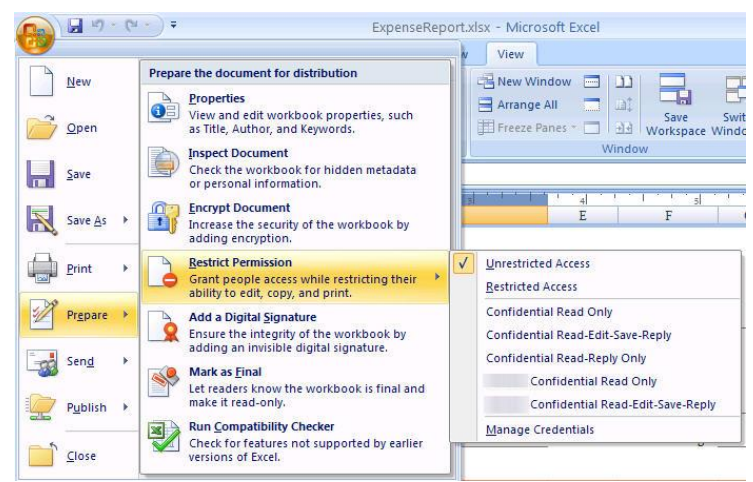

Gambar 7. DRM pada Microsoft Office Word 2007

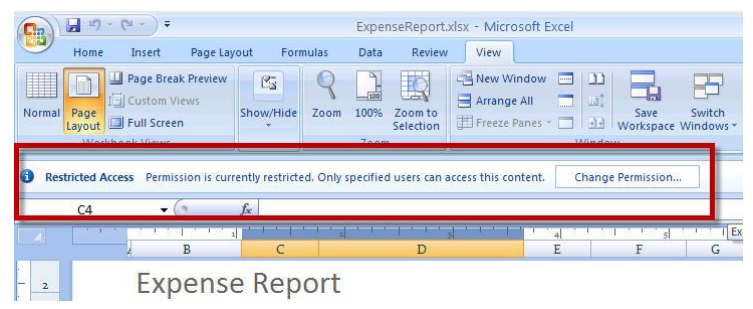

Gambar 8. Informasi ketika dokumen DRM tidak dapat diakses oleh user yang tidak berhak

Dengan konsep user interaction, kita juga dapat meampilkan apabila ada dokumen yang mana user tidak mempunyai akan diinformasikan seperti pada Gambar 8 . 


\subsection{Prinsip Kerja}

Dokumen elektronik yang akan diterapkan DRM maka user pemilik dokumen akan melakukan proses sebagai berikut ini:

1. User yang bermaksud untuk memproteksi dokumen harus mendaftarkan komputer dan domain user account ke DRM CA. Ini dapat melakukan aplikasi client yang berbasis DRM. Mesin komputer yang sudah didaftarkan akan mendapatkan machine certificate sedangkan identitas user akan memperoleh Rights Account Certificate.

2. Selanjutnya user akan mengunduh Certificate dari DRM Server dan mengaktifkannya

3. Setelah user mengaktifkan Certificate, user membuat Issuance License yang berisi hak akses yang akan diterapkan pada dokumen tersebut seperti Read-Only, Don't Forward, Editable, Print dan sebagainya. Issuance License juga dapat diberlakukan masa aktifnya sesuai dengan kebutuhan.

4. Kemudian Issuance License yang telah dibuat dikirim ke DRM Server untuk dilakukan proses signing sehingga nantinya dapat didistribusikan apabila user lain mengakses dokumen ini. User pemilik Issueance License akan memperoleh Owner License.

5. Dengan menggunakan Owner License, user kemudian melakukan proses editing dokumen

6. Apabila selesai proses editing maka aplikasi akan melakukan enkripsi isi dokumen dan mengirimnya ke DRM Server

Sedangkan user lain yang ingin mengakses dokumen berbasis DRM maka proses yang dilakukan adalah

1. Ketika user membuka dokumen berbasis DRM maka aplikasi client yang aware terhadap DRM akan meminta end-user License ke DRM Server dengan dengan informasi pada dokumen DRM tersebut

2. Sebelum memperoleh end-user License maka user akan dicek melalui Directory Service apakah user tersebut member dari DRM Server atau tidak

3. Apabila proses pengecekan selesai dan ternyata bukan member DRM maka user tersebut tidak dapat memperoleh end-user License

4. Jika user merupakan member DRM maka user akan memperoleh end-user License dari DRM Server

5. End-user License berisi informasi hak akses yang dimiliki terhadap dokumen yang dibuka Apabila user mempunyai hak akses minimal dapat melihat (view) maka aplikasi akan melakukan dekripsi melalui public key yang sudah disediakan

\subsection{Integrasi dengan Sistem E-mail}

Apabila dokumen DRM ini diletakan pada e-mail sebagai attachment file maka pada dasarnya aplikasi client e-mail akan melakukan attachment suatu dokumen yang terenkripsi.

Kemudian user mengirim e-mail dengan attachment file dokumen DRM ke target penerima mail server. Setelah sampai pada target penerima mail server maka attachment tetap dalam bentuk enkripsi DRM yang tersimpan pada storage mail server tersebut.

Dari analisa proses yang terjadi diatas maka kita dapat mengatakan dokumen DRM tetap tersimpan aman karena dokumen DRM tersebut tetap pada kondisi terenkripsi.

Ketika user yang menerima email yang di dalamnya ada attachment dokumen dan e-mail sudah masuk ke dalam aplikasi e-mail client. Kemudian user membuka attachment dokumen DRM. Apabila aplikasi e-mail client tersebut tidak mengenal format dokumen DRM maka aplikasi tetap tidak dapat membuka dokumen DRM.

\subsection{Integrasi dengan Aplikasi Email Client}

Agar aplikasi email dapat membuka dokumen DRM maka aplikasi email harus dibuat supaya aware terhadap dokumen DRM. Guna keperluan ini, kita dapat membuat aplikasi baru yang mengerti sistem DRM kita atau membuat add-on pada aplikasi yang ada.

Selain aplikasi email client yang aware terhadap DRM maka kita dapat membuat interaksi dengan user melalui pendekatan GUI yang komprehensif. Misalkan kita ingin email yang akan dikirim dapat diberlakukan sebagai

- Read-only email. Disini email hanya dapat dibaca tetapi tidak dapat disimpan atau di-print

- Do not forward. Ini email yang dikirim ke user tertentu maka penerima tidak dapat melakukan forward ke email lain

Sebagai contoh implementasi DRM pada aplikasi client email yaitu Microsoft Right Management Services (RMS) seperti pada Gambar 9.

\subsection{DRM pada Sistem Blackberry}

Era mobilitas teknologi informasi semakin meningkat ditambah dengan kehadiran sistem Blackberry dari RIM (Research In Motion). Sistem ini bekerja dengan melibatkan telekomunikasi provider sehingga ini dapat meningkatkan tingkat mobilitas. Dengan tool kita dapat mengakses email atau sekedar menjelajah dunia internet. 


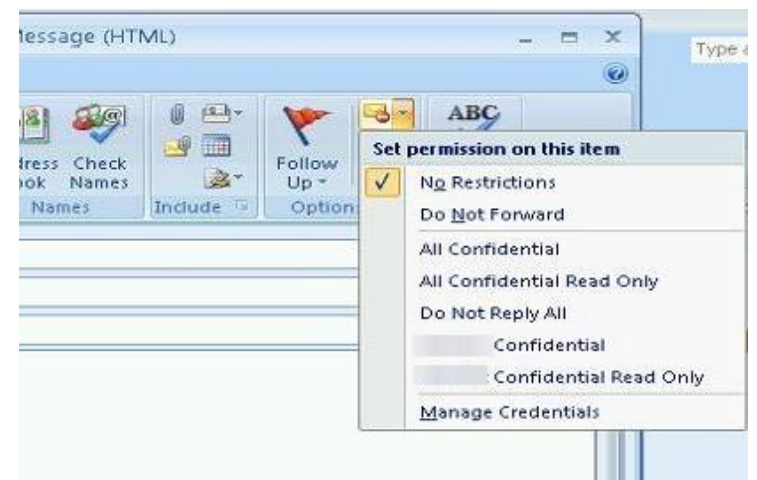

Gambar 9. Pemilihan keamanan dokumen pada aplikasi client email

Kalau kita melihat sistem email yang diberikan pada RIM maka sebenarnya di sisi RIM semua email akan menjadi transparan sehingga data atau dokumen email yang dikirim melalui RIM akan terbuka. Hal ini sangat menjadi kendala ketika mengamankan data atau dokumen pada Blackberry.

Solusi untuk mengamankan data atau dokumen pada email di Blackberry adalah dengan membuat aplikasi middleware yang dapat berkomunikasi dengan Blackberry Enterprise Server (BES) dan DRM Server. Contoh solusinya dapat dilihat seperti Gambar 10. Solusi ini memerlukan dua aplikasi middleware yaitu:

- DRM-Blackberry Server

- DRM Agent pada BES

Proses yang terjadi dengan pendekatan solusi seperti Gambar 9 sebagai berikut:

1. Pada Blackberry client menerima email yang tidak ada DRM maka Blackberry client akan langsung berkomunikasi dengan BES.
2. Apabila Blackberry client menerima email yang didalamnya terdapat dokumen DRM maka ketika email ini dibuka Blackberry client akan meminta dokumen DRM ke BES dengan meminta permission ke DRM server melalui DRM Agent pada BES dan DRM-Blackberry server.

3. DRM-Blackberry ini yang akan bertanggung jawab apakah user pada Blackberry client mempunyai hak akses atau tidak. Selain itu, DRM-Blackberry juga melakukan enkripsi/dekripsi data atau dokumen DRM.

4. Untuk user yang akan mengirim email dengan DRM maka ketika email sampai di BES maka DRM agent pada BES akan melakukan enkripsi melalui DRM-Blackberry server. Setelah selesai, email tersebut dikirim ke RIM.

Beberapa perusahan IT juga sudah membuat aplikasi pada Blackberry supaya dalam memproses data yang berbasis DRM. Salah satu vendor yang fokus terhadap ini adalah GigaTrust [6].

\subsection{Klasifikasi Dokumen}

Selain mengamankan dokumen elektronik supaya tidak diakses oleh orang yang tidak berhak, kita juga harus memikirkan untuk menentukan dokumen apa yang dapat dikatakan sebagai dokumen yang layak untuk diamankan. Hal ini sangat penting supaya sistem dapat digunakan secara efisien.

Ada banyak metode untuk mengklasifikasi dokumen dapat dikategorikan dokumen penting atau tidak. Pada umumnya klasifikasi dokumen berdasarkan kebutuhan dan jenis lembaga/institusi/perusahan yang akan menerapkan DRM ini.

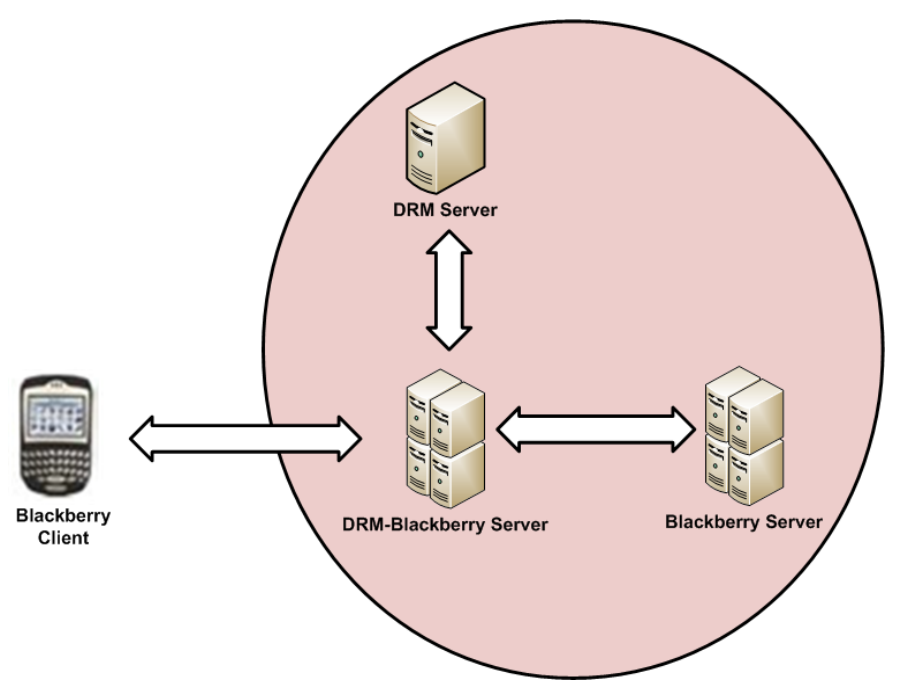

Gambar 10. Solusi DRM pada Blackberry 


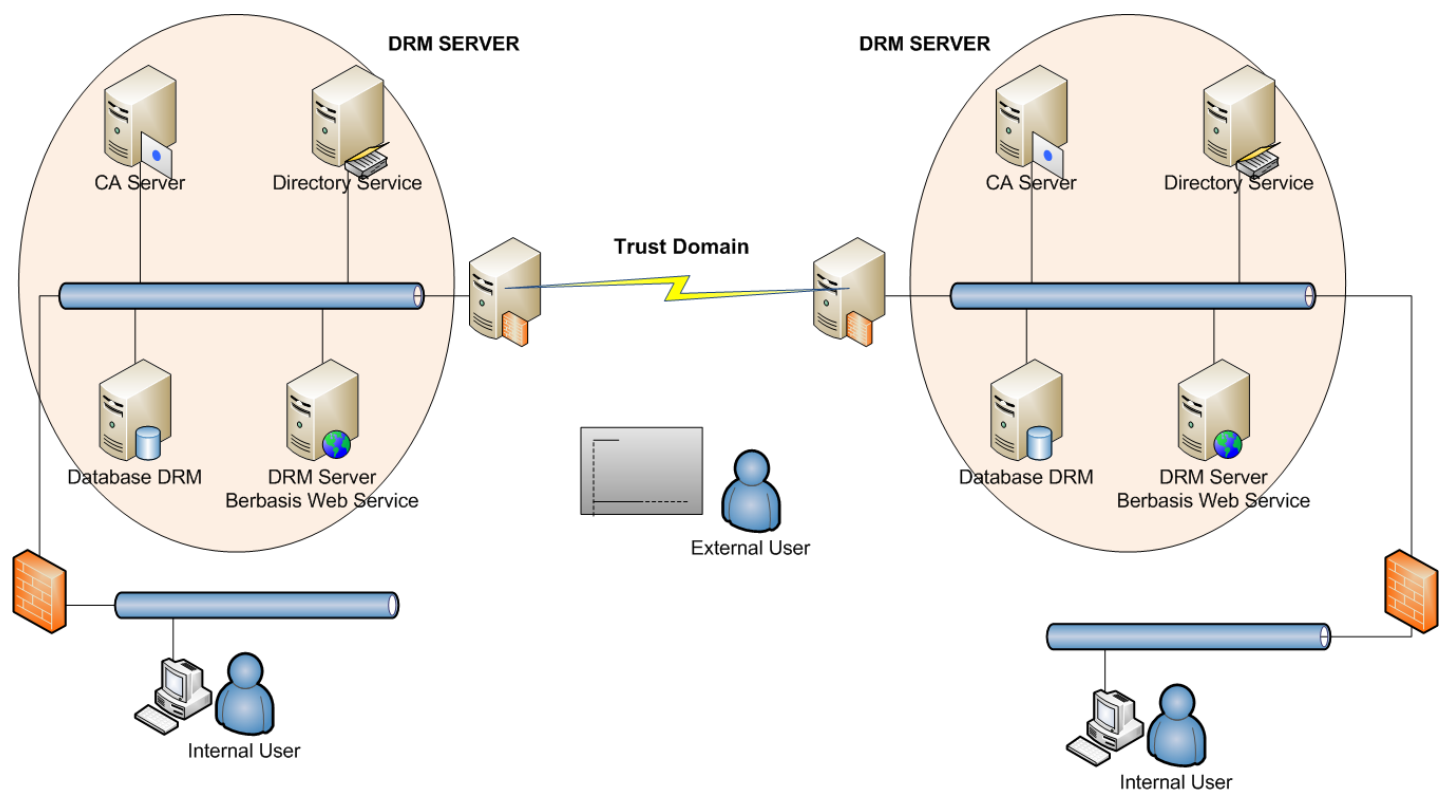

Gambar 11. Implementasi DRM untuk B2B

Apabila kita sudah melakukan klasifikasi jenis dan tipe dokumen yang termasuk dokumen yang harus diamankan, kita selanjutnya dapat membakukan sebagai standar baik dalam bentuk SOP (Standard Operational Procedure) atau undang-undang. Ini diharapkan dapat melancarkan proses implementasi sistem ini.

Jika klasifikasi sudah ditentukan maka kita juga dapat menerapkan pada aplikasi client DRM dengan memberikan label dokumen, contohnya dapat diterapkan pada Microsoft Office Word 2007 seperti Gambar 6. Label ini akan memberikan keamanan sesuai dengan yang ditentukan.

\subsection{Kolaborasi Dokumen DRM untuk Kebutuhan B2B}

Implikasi untuk kolaborasi dokumen berbasis DRM untuk lingkungan B2B (Business-to-Business) dapat diterapkan apabila semua entitas menerapkan trust domain terhadap terjadi transaksi yang terjadi baik pada Directory Service, DRM Server dan CA Server.

Semua pihak yang terlibat kolaborasi dokumen DRM harus memberikan hak akses sistem lain untuk melakukan authentikasi dan verifikasi user dari setiap sistem. Secara umum desain untuk kolaborasi DRM untuk B2B dapat dilihat pada Gambar 11.

\section{Kesimpulan}

Penerapan dokumen elektronik yang berbasis DRM diharapkan melindungi informasi didalamnya terhadap orang-orang yang tidak mempunyai kepentingan. Tingkat kesuksesan penerapan dokumen berbasis DRM juga ditentukan kesiapan user.

\section{REFERENSI}

[1] M. K. Buckland, "What is a "document"?", Journal of the American Society of Information Science, 48 (9), 1997.

[2] Michael Buckland, "What is a digital document"?, Document Numérique (Paris) 2, no. 2 (1998): 221-230, 1998

[3] INDICARE, Consumer's guide to Digital Rights Management, INDICARE Project, April 2006.

[4] Microsoft, Windows Rights Management Services, http://www.microsoft.com/rms

[5] Nilay Patel, iTunes Plus DRM-free, not free of annoying glitches, http://www.engadget.com/ 2007/05/31/itunes-plus-drm-free-not-free-ofannoying-glitches/

[6] GigaTrust, www.gigatrust.com, Roberto Garcia Gonzalez, A Semantic Web approach to Digital Rights Managements, PhD. Thesis, Universitat Pompeu Fabra, November 2005. 